\title{
PLATO’S LEGAL POSITIVISM IN THE LAWS*
}

\author{
Antony Hatzistavrou
}

INTRODUCTION

In this paper, I reassess the place of Plato's Laws in the history of legal thought. In virtue of the account of law that he presents in the Laws, Plato has been traditionally credited with a natural law theory of law. ${ }^{1}$ I challenge that 'orthodox' interpretation and argue that in the Laws Plato presents an account of the nature of law that belongs to the tradition of legal positivism.

I would like to make the following preliminary clarifications about the argument that I advance. First, I do not discuss the issue of whether Plato is committed to a natural theory of morality in the Laws (or indeed in any other dialogue). For the purposes of this paper I remain agnostic about the general character of Plato's theory of morality, that is, about whether Plato's moral theory is best classified as belonging, for example, to the tradition of deontology, utilitarianism, virtue ethics or natural law. ${ }^{2}$ My agnosticism has no bearing on

\footnotetext{
* Earlier drafts were presented at a meeting of the Ancient Philosophy Workshop at the University of Oxford, at a meeting of the Yorkshire Network for Ancient Philosophy and at a Royal Institute of Philosophy conference on Ancient Legal Philosophy at the University of Hull. I am grateful for comments received on those occasions as well as to written comments from two anonymous referees of this journal.

${ }^{1}$ Supporters of the natural law interpretation of Plato's account of law in the Laws include Jerome Hall 'Plato's legal philosophy’ (1956) 31 Indiana Law Journal, 171, Glen Morrow Plato’s Cretan City (Princeton University Press, 1960) 565-572, John Finnis Natural Law and Natural Rights (Clarendon Press, 1980) 363 and 407-408, Richard F Stalley An Introduction to Plato's Laws (Blackwell, 1983) 23-34, David Cohen 'Law, Autonomy and Political Community in Plato’s Laws' (1993) 88 Classical Philology 301, Terence Irwin 'Morality as law and morality in the Laws' in Christopher Bobonich (ed) Plato's Laws A Critical Guide (Cambridge University Press, 2010) 99-100, Fred D Miller 'The rule of law in Plato’s Laws' in Jacob A Jacobs (ed.), Reason, Religion and Natural Law: From Plato to Spinoza (Oxford University Press, 2012) 50-51. Dorothea Frede 'Puppets on strings: Moral Psychology in the Laws: Books 1 and 2' in Christopher Bobonich ibid 117-118 and Christopher Rowe 'The relationship of the Laws to other dialogues: A proposal' in Bobonich ibid also support the current orthodoxy though they do not directly address the issue of the relation of Plato's account of law to the natural law tradition.

${ }^{2}$ I assume that a natural law theory of morality denotes something more concrete than simply an objectivist meta-ethical theory, for example, a theory of morality according to which moral facts are grounded in facts about human nature, which enables a meaningful contrast with other meta-ethical theories. For different ways in which a natural law theory of morality may be understood see Michael S Moore, 'Law as functional kind' in Robert P George (ed.) Natural Law Theory: Contemporary Essays (Clarendon Press, 1994) 190-91.
} 
my discussion of the natural law credentials of Plato's theory of law in the Laws. Even if Plato were considered to present a natural law theory of morality in the Laws, the question about the nature of his theory of law would remain open. For a natural law theory of morality does not entail a natural law theory of law. ${ }^{3}$ One who adopts the former may consistently deny that posited law and objective morality are necessarily linked. For example, this appears to be the position of one of the fathers of modern legal positivism, John Austin. ${ }^{4}$

Second, by a 'natural law theory of law' I understand primarily a theory about the nature of law according to which unless the content of legal norms is consistent with the content of objective moral norms, then those norms are not legal norms or at least they are defective qua legal norms and systems of those norms are not legal systems or at least they are defective qua legal systems. ${ }^{5}$ The necessary convergence between legal and objective moral norms is meant to extend beyond trivial facts, for example, the fact that in all legal systems there may be legal prohibitions against murder or that a legal system would not be viable if human beings were incapable of some level of self-control or limited altruism. ${ }^{6}$ It is that understanding of natural law theory of law that guides my argument in the third section of this paper. In the fourth section, however, I expand the scope of my argument so as to examine whether Plato may be committed to a different version of a natural law theory of law that in contemporary jurisprudence is normally associated with Lon Fuller and according to which the rule of law has intrinsic moral merit. By contrast, I understand by 'legal

\footnotetext{
${ }^{3}$ Some believe that one may hold a natural law theory of law even though one does not espouse a natural law theory of morality (see for example, Mark C Murphy, Natural Law in Jurisprudence and Politics (Cambridge University Press, 2006) 4. For an opposite view see Moore (n 2) 192.

${ }^{4}$ Austin believed that natural law, which he equated with the unrevealed divine laws, can be known by human reason using the principle of general utility as an index (John Austin, The Providence of Jurisprudence Determined (J. Murray, 1885), 103-110).

${ }^{5}$ For the purposes of this paper I do not strictly differentiate between the strong natural law thesis that unjust laws are not laws and the weak natural law thesis that unjust laws are deficient qua laws (for the distinction between those two theses see Murphy (n 3) 10-11). As will become clear from the subsequent discussion, I do not take Plato to subscribe to either of those theses in the Laws.

${ }^{6}$ The relevant truisms constitute what Hart calls the 'minimum content of natural law' (see Herbert L A Hart, The Concept of Law (Clarendon Press, 1994) 193-200).
} 
positivism' a theory about the nature of law that denies both the existence of a non-trivial, necessary link between the content of legal norms and the content of objective moral norms and the intrinsic moral merit of the rule of law and that grounds the existence of law on social facts.

Third, I discuss exclusively Plato’s account of the nature of law as presented in the Laws and do not offer a comprehensive interpretation of the theory of law presented in the whole Platonic corpus (that is, in genuine Platonic dialogues like the Republic, the Crito or the Gorgias). On the one hand, the Laws is singled out because it contains Plato's most extensive and systematic treatment on legislation. That is the reason why the supporters of the natural law interpretation of Plato's theory of law ground their interpretation primarily in some key passages of the Laws. On the other hand, a comprehensive interpretation of the theory of law presented in the whole Platonic corpus would require one to tackle issues concerning the continuity or development of Plato's political and legal thought and the specific philosophical aims of individual dialogues which is a task that far exceeds the scope of this paper. For example, there are arguably differences between the political projects of the Republic and the Laws that potentially reflect different conceptions of the political function of law. It could be argued that in the Republic Plato proposes that the rule of philosophers who possess the highest form of knowledge is constrained by law. On that interpretation, the main reason for giving the reins of power to philosophers is that they are able to preserve the laws of the perfect city (484b9-c2; cf. 458b9-c5). As I explain in section 2, in the Laws, however, he argues that it is inappropriate for the rule of knowledge to be constrained by law since law cannot deal as well as expert political knowledge with the complexity and fluidity of human affairs. This kind of potential difference of opinion about the political function of law calls for careful examination of the continuity or development of Plato's theory of law and recommends caution in using ideas found in one dialogue to interpret ideas found in 
another. Though I believe that the positivist account of the nature of law that Plato presents in the Laws is consistent with remarks he makes about the nature of law in other dialogues, ${ }^{7}$ in this paper I only try to substantiate the claim that Plato presents a positivist account of law in the Laws and I do not advance an overall interpretation about the continuity or development of Plato’s account of the nature of law.

I proceed as follows. In the first section I introduce Plato's project in the Laws and explain that a historian of legal thought may legitimately inquire about Plato's account of the nature of law in the Laws. In the second, I discuss the genealogy of law, the account of law as a tyrannical command and the conception of political and legal order that are presented in the Laws and argue that they suggest a positivist theory of law. In the third I explain that the natural law interpretation of the account of law presented in the Laws misconstrues the import of some key passages of the dialogue and argue for a positivist interpretation of the relevant passages. In the fourth I reject the possibility that the rule of law has inherent moral merit in the Laws. I conclude with some reflections on the distinctiveness of Plato's legal positivism as presented in the Laws.

\section{PLATO’S LAWS AND INQUIRY INTO THE NATURE OF LAW}

The Laws describes a lengthy discussion about legislation between three elderly men, an Athenian who remains unnamed, the Spartan Megillus, and the Cretan Cleinias. The Athenian is widely assumed to be the voice of Plato in the dialogue and in this paper I follow this widely shared assumption. Most of the discussion concerns the legal code of an imaginary city, Magnesia, which is described as the 'second-best' political and legal order

\footnotetext{
${ }^{7}$ I explore this issue in Antony Hatzistavrou 'The law and its functions' in Vassilis Politis and Peter Larsen (eds) The Platonic Mind (Routledge 2017) (forthcoming).
} 
(politeia). ${ }^{8}$ On the one hand, since the institution of property exists in Magnesia, it is second to a regime of complete communism which alone can produce the greatest unity in a city (739b8-e4). So, the political and legal order of Magnesia falls short of the highest standards of political unity. On the other, it is second to the rule of the true political expert described in the Statesman. Magnesia exemplifies the rule of law that is inferior to the rule of political expertise because law, unlike expert political judgement, cannot deal with the complexity and fluidity of human affairs (see T2 and T3 in section 2.3).

The Athenian is primarily concerned with normative jurisprudence. He identifies the end that a morally good political and legal order should aim at, namely, the regulation of public life in line with not only the precedence of virtue over non-moral ends, like health and wealth, but especially the hierarchy of the four cardinal virtues, that is, wisdom, moderation, justice and courage, which gives absolute priority to wisdom (631c5-d2). ${ }^{9}$ And he proposes a detailed legal framework that enables Magnesia to meet that end. But he also engages with questions about the nature of law. He offers two definitions of law, namely, law as calculation of what is good for the city that is accepted by the citizens (641d1-3) and law as a distribution of reason (T4 in section 3.1). He traces the historical origins of legal systems and develops a genealogy of law. He also differentiates law in the strict sense as a tyrannical command from law understood loosely as including educational preambles to legislation (T1 in section 2.3). So, a historian of legal thought may legitimately scrutinize the consistency of the Athenian's definitions of law, explore the implications of his genealogy of law and

\footnotetext{
${ }^{8}$ I explain my translation of politeia as 'political and legal order' in section 2.4.

${ }^{9}$ Wisdom is prior to all other virtues because if one lacks wisdom one fails to be genuinely just, self-controlled or courageous (see $n$ 49). Furthermore since for the Athenian virtue and happiness go together (660e2-661d5 and 742e4-5), a political and legal order that respects the hierarchy of the four cardinal virtues will also be happy (697a10-c3). That is why the Athenian occasionally refers to happiness as the end of a good lawgiver (see, for example, 743c5-6).
} 
analyse his account of law in the strict sense. Those are the tasks that I undertake in the following sections.

\section{THE POSITIVIST INTERPRETATION: INITIAL EVIDENCE}

\subsection{Plato's genealogy of law}

The Greek for law is nomos. For the Athenian, nomos is, strictly speaking, 'written law' that differs from the unwritten customs (ethê) of primitive clans (679e6-680a8). Though he occasionally calls the unwritten customs of primitive clans 'laws' (681b6 and 681c1), he makes clear that for him unwritten customs are not, strictly speaking, laws (793b2-4).

We may identify three basic elements of the genealogy of law that the Athenian presents in book 3 of the Laws:

(a) A legal system is a social construction based on custom that is defined by the presence of the main agents of law, namely legislators and rulers, whose task is to select laws from pre-existing customs and rule in accordance with them.

The Athenian locates the origin of legislation at the transition from simple isolated clans to larger social units. Isolated clans are ruled by the eldest male who issues commands to the rest of the clan. His commands express his personal choices or inclinations (haireseis) and are impressed on the minds of his dependents with the result that each clan is ruled by its own diverse customs (681a7-b7). So, members of each clan accept (areskein, 681c1) their own customs and are disinclined towards the customs of another clan (681c1-2). ${ }^{10}$ But when

\footnotetext{
10 Though in this context the Athenian speaks of 'laws' of different clans he uses 'law' here in a loose sense to mean customs.
} 
different clans come together there is need for the creation of written common standards of conduct. Consequently, representatives from different clans are selected. They are called 'legislators' and their task is to develop a common legal code by selecting from the different customs of each clan. The lawgivers recommend their selection to the leaders of each clan who become the rulers of the new political community (681c7-d5).

(b) The main agents of law have a critical attitude towards it. By contrast, the subjects' attitude towards law is defined by their entrenched attachment to their clan customs that they habitually obey; the closer the affinity of the posited laws of a city to the clan customs the greater the attachment they feel towards them.

The main legal agents have a critical attitude towards the laws: they have selected them from pre-existing customs as legislators and approved of them as leaders. But no such critical attitude is required by the subjects. Rather they are simply expected to obey perhaps in the habitual manner in which they obeyed the deeply entrenched customs of their clans.

(c) The provision of laws is enriched by decisions of the main legal agents or joint agreements between legal agents and subjects.

Eventually different legal systems of various degrees of complexity develop. ${ }^{11}$ In their most complex form they include binding agreements either between the kings of different citystates with one another or between the kings and their citizens. They concern primarily the exercise of power of the kings and rules of mutual assistance (684a2-b11) and are motivated by fear of military attack by external enemies (685b7-c5). They have little in common with original clan customs and are the result of explicit agreement.

\footnotetext{
${ }^{11}$ In the Athenian's narrative they are exemplified by Troy (681e1-682e6) and the Dorian League (683c8-d5).
} 
The Athenian’s genealogy of law in book 3 does not conflict with his occasional references in the Laws to the gods' being the source of legislation. As Malcolm Schofield rightly comments, 'the Laws never pretends that law is anything other than the work of human legislators'. ${ }^{12}$ The Athenian's point is simply that morally good laws (that is, laws that respect the hierarchy of the four cardinal virtues) may be considered to be the result of divine inspiration of human lawgivers. That is why he is willing to entertain the assumption that the laws of Sparta and Crete are divinely inspired provided that it is shown that they correctly represent the hierarchy of the four cardinal virtues (630b4-e2) (an assumption which he ultimately drops since he finds that their laws are significantly morally flawed). ${ }^{13}$ Divine inspiration may occur either at the selection of laws from pre-existing customs or at the stage of enacting more complex legislation.

\subsection{Law as a tyrannical command}

The Athenian also provides an account of how individual legal norms purport to affect the reasoning of legal subjects. In book 4 of the Laws he explains that in Magnesia laws should be accompanied by preambles (prooimia) (722d1-4). The purpose of the preambles is to persuade the citizens about the correctness of specific laws, or even the whole of legislation (723b3-6), and thus make them obey the law willingly and in a cooperative frame of mind. He also compares the legislator who does not use persuasion to a doctor who treats slaves as opposed to free men (719e7-720e6). Initially he speaks as though preambles are part of law. He repeatedly calls laws that are accompanied by preambles ‘double laws’ (720e7, 721b5, 721d8). But later he clarifies that laws and preambles are two different things:

\footnotetext{
${ }^{12}$ Malcolm Schofield, Plato (Oxford University Press, 2006) n 49 at 329.

13 See also n 19.
} 
$\mathrm{T} 1$ '...the laws that I mentioned just now are not in the most accurate sense of the word 'double' (ouk einai haplôs houtôs pôs diploi) but there are two things: law and preamble to law. The tyrannical command that is similar to the commands issued by those doctors whom we said to treat slaves is 'pure' (akratos) law. What is mentioned before this and which was said to be and actually is persuasive has the power of a preamble in a speech. For, as has become clear to me, the speech that aims at persuasion is constructed with this purpose in mind: so that the person whom a legislator addresses with a law accepts with good will (eumenôs) the command, which is of course the law, and due to his good will becomes readier to learn from it. For that reason in accordance with my argument that thing should be properly (orthôs) called 'preamble' and not the 'voice' of law.' (722e5-723b2)

So, 'law' in the strict, proper sense of the term is a command. The characterization of that command as tyrannical indicates that it possesses three interrelated features.

First, the purpose of law is simply obedience in the sense of behavioural conformity with its content and not persuasion. That becomes clear by the way the Athenian draws the contrast between the doctors of slaves and the doctors of free men. The former neither provide an account of the disease for which they prescribe nor accept any account offered to them by their patients (720c3-5). By contrast, the doctor of free men reasons with his patients, tries to explain to them his account of their disease, learns from them about their symptoms and experiences and does not prescribe a treatment before he has convinced them (720d3-e2).

Secondly, law, like a tyrant, makes a (false, as I explain shortly) claim to possess expert knowledge. That claim should be understood as an implication of law’s illocutionary act of commanding. Law takes the issue for which it prescribes to be settled by the content of its command. But for the Athenian any issue can only be properly settled by expert knowledge. The analogy of the legislator who only puts forward laws without preambles with the doctor of slaves illustrates the point. The Athenian claims that the doctor of slaves gives prescriptions headstrongly (authadôs) like a tyrant (720c6-7). The attitude of the doctor of slaves is compared to the headstrongness of tyrants because he issues medical prescriptions 
as if he had precise knowledge (hôs akribôs eidôs, 720c6). In reality he only prescribes what appears correct to him based only on his experience (empeiria, 720c6).

Why should we think that the medical prescriptions of doctors of slaves and per analogy laws are epistemically defective? Doctors of slaves do not themselves study the nature of diseases. They form opinions about medical issues through experience by following the commands and watching the activities of expert doctors, namely, the doctors of free men (720b2-6). Furthermore, the latter because they consult the patients and their relatives about their diseases make prescriptions that are to a great extent individualised and do not have the general sweeping scope of the prescriptions of the doctors of slaves. So, their knowledge is precise in two senses: it is based on (a) a proper general understanding of the nature of diseases and also (b) a detailed account of the symptoms and overall health condition of individual patients. By contrast, the doctors of slaves lack precise medical knowledge in either of those two senses.

Law resembles the epistemic defect of the medical prescriptions of the doctors of slaves. In book 9 the Athenian contrasts the rule of law with the rule of that rare species, the political expert who could control his desire for self-aggrandisement, and finds it wanting:

T2 ‘...[that political expert] would need no law to rule over him. For no law or any kind of order is better than knowledge and it is not pertinent for reason (nous) to be the subject or the slave of anyone but it should rather be the ruler of all, if it is true and free according to nature. As things are now, however, it is nowhere to be found except only to a small extent. That is why one must choose the second alternative, namely law and order, which can supervise most things though it cannot provide for every case'. (875c4-d5)

A similar view about the epistemic defect of law is voiced by the Eleatic visitor in the Statesman:

T3 '...law could never accurately embrace what is best and most just for all at the same time, and so prescribe what is best; for the dissimilarities between human beings and their actions, and the fact that practically nothing 
in human affairs ever remain stable, prevent any kind of expertise whatsoever from making any simple decision in any sphere that covers all cases and will last for all time.' (294a10-b6) ${ }^{14}$

So, by its very nature law is epistemically defective in the following sense: since laws are by nature general, they fail to do justice either to individual differences or to the change of circumstances both of which are integral features of the human condition. This means that (a) what laws prescribe occasionally diverges from what the political expert would prescribe in the circumstances; and (b) when one assumes the task of legislation one operates in a fashion uncharacteristic of political expertise since one disregards two integral features of the human condition. (One behaves as if, like a doctor of slaves, one relied on experience rather than precise knowledge.)

In view of the above I suggest that we understand the second main feature of law as a tyrannical command, as follows: law claims to possess political expertise even though it is epistemically defective.

The final feature of law as a tyrannical command is that it is backed by threats. Laws include penalties for disobedience which may be direct punishment or deprivation of honours. The threats included in laws enable it to operate through compulsion (bia, 718b2) and affect the citizens' practical reasons in favour of conformity. The coercive aspect of law is most directly contrasted to the persuasive function of the preambles.

\subsection{A positivist account of law?}

\footnotetext{
${ }^{14}$ Rowe's translation revised for John Cooper (ed.) Plato Complete Works (Hackett, 1997).
} 
Let us reflect on the Athenian's genealogy of law and his account of law as a tyrannical command. The Athenian identifies central cases of legal systems, differentiates them from proto-legal social arrangements and explains their complexity without engaging in moral evaluation of the content of their norms of public conduct. Rather he identifies legal systems by reference to social facts. The relevant social facts include (a) the selection by clan leaders of certain norms of conduct from a pool of customs peculiar to those clans; (b) the division of labour between the main legal agents, namely, legislators and rulers; and (c) a nexus of agreements between rulers of different states and between rulers and subjects that explains the generation of complex legal systems.

In a similar manner, the Athenian identifies individual legal norms without morally evaluating their content. An individual legal norm is identified by reference to its social origin and the mode of its operation. On the one hand, it is established by an act of legislation and either it originates in a clan custom that reflects the inclinations of the clan leaders or it is the result of an agreement between rulers or between rulers and subjects. On the other, it operates as a tyrannical command that aims not at persuasion but at behavioural conformity with its content, makes a false claim to possess true political knowledge and relies on the use of threats.

There is, thus, initial evidence for crediting the Athenian with a positivist account of law. That evidence, however, needs to be treated carefully. On the one hand, we need to examine whether there is any conflicting textual evidence that supports the natural law interpretation. For if there were independent textual evidence for the natural law interpretation, the Athenian's genealogy of law and his account of law as a tyrannical command may be thought to identify only the conditions that a determination of a precept of natural law needs to satisfy to become a posited norm. I examine the relevant textual 
evidence in section 3.1. On the other hand, we need to clarify the Athenian's conception of politeia as it poses restrictions to the type of systems of norms that count as genuine legal systems. I undertake that task in the following section.

\subsection{The Athenian's conception of politeia}

The Athenian uses politeia in two senses. On the one hand, politeia in a broad sense denotes any type of political arrangement or constitution. The Athenian uses politeia in this sense when he refers to the structure of primitive societies that lacked written laws (689a9) and to the two mother constitutions, monarchy and democracy, from which all other constitutions derive (693d2-7). By calling monarchy and democracy 'mother' constitutions the Athenian does not mean that all existing political constitutions historically developed from two original political constitutions, one monarchical and the other democratic. Rather he treats monarchy and democracy as ideal types that exemplify two distinct political values, political freedom and subordination, that frame the political ideology of all existing constitutions. Some political constitutions tend to endorse one of those values at the expense of the other. For example, Persian constitutions on the whole tend to promote total subordination of the subjects to the rulers while Athenian constitutions on the whole tend to treat freedom as the supreme political value (693d5-6, e5-7). Other political constitutions exemplify different combinations of the two political values. The latter include Sparta and Crete and some Athenian and Persian constitutions at different historical junctures (693e7694a1).

On the other hand, the Athenian also uses politeia in a narrow sense. In book 4 he contrasts Sparta and Crete which he considers to be genuine instances of politeia (ontôs ...politeiôn metechete, 712e9) with traditional aristocratic, oligarchic and tyrannical regimes 
which disqualify from being genuine instances of politeia on the ground that they are extremely despotic (712e9-713a4). In book 3 he criticizes both the extreme authoritarianism of the Persian empire during the reign of Cambyses and Xerxes and the anarchy that prevailed in democratic Athens after the Persian wars suggesting that neither of those regimes is well-constituted (see politeuthênai...kalôs, 693e1-3).

What is then politeia in a narrow sense? It is a political arrangement that has an order (taxis) due to written law (875d4-5; cf. 632d4-5 and 780d5-8) ${ }^{15}$ and that meets some evaluative standard. That standard is defined in book 3 of the Laws as a combination of ‘freedom’ (eleutheria), ‘friendship’ (philia), and some collective intellectual quality variously described as ‘wisdom' (phronêsis), or ‘soundness of mind’ (sophrônein) or 'reason’ (nous) (693d8-e1, 693b3-5, c2-3, c6-7, 701c8-9). ${ }^{16}$ How that standard is understood is crucial to assessing the natural law credentials of the Athenian's account of the nature of law. If that standard is satisfied only if the regulation of public life by law is in line with the hierarchy of the four cardinal virtues, then a strong case may be made in favour of a natural law interpretation of the Athenian's account of the nature of law. On that interpretation, a particular regime counts as a genuine instance of a politeia in a narrow sense only if the content of political friendship, freedom and collective intellectual quality that its laws promote is shaped by and expresses or approximates the hierarchy of the four cardinal virtues. $^{17}$

\footnotetext{
15 The Athenian treats the primitive clans that lacked written laws as only 'a kind of' political order (see tropos tis, 680a9) which suggests that for him all politeiai in a narrow sense have written laws.

${ }^{16}$ In book 4 the Athenian speaks of the promotion of the good of the whole city as a defining feature of politeia in a narrow sense. As I explain in section 3.4 'promotion of the good of the whole city' is equivalent to the description of the evaluative standard presented in book 3 as a combination of freedom, friendship and some collective intellectual quality and ultimately refers to the political compromise between rulers and subjects that enables a city to attain an adequate level of political stability.

${ }^{17}$ In other words, a politeia in a narrow sense is a constitution that values the virtue of wisdom above all other virtues and understands that the other virtues are genuine to the extent that they are guided by wisdom. See also n 49.
} 
This is not, however, how the Athenian appears to understand the relevant evaluative standard when he introduces it in book 3. He presents as genuine instances of a wellconstituted political and legal regime or else of politeia in a narrow sense, Sparta, Crete, the Persian empire during the reign of Cyrus and Darius and Athens during the Persian wars (693e6-694a1). ${ }^{18}$ In none of those regimes do laws express or approximate the hierarchy of the four cardinal virtues. Sparta and Crete misrepresent the hierarchy of the four cardinal virtues by mistakenly treating courage as the most important virtue (630d2-631b2 and 633a4634c4) and by promoting practices of great immorality. For example, the Athenian criticizes the Spartan and Cretan institutions of common meals and gymnastic exercises for promoting homosexuality and lesbianism which he considers unnatural practices (636a4-d1). And in book 2 of the Laws he lambasts their education concluding that it fits an army camp rather than a political community and it totally fails to make people good citizens (666e1-667a5). The Persian empire during the reigns of Cyrus and Darius pursued material ends, like territorial expansion and increase of material wealth (694c6-695a1 and 695d4-6) which are the least valuable political ends (631c4-5). Similarly, the Athenian democracy during the Persian wars was concerned primarily not with virtue but with fending off the military threat of the Persians (698b7-c3). ${ }^{19}$

\footnotetext{
${ }^{18}$ The Athenian's statement that those regimes are genuine instances of well-constituted political and legal regimes expresses his own evaluation of the merits of those regimes and does not simply report how citizens of those regimes or his interlocutors evaluate their merits. This becomes clear by the fact that he proceeds to offer a justification for his statement (694a1) in which he clearly expresses personal views (see for example, 694c5). So it is not possible for supporters of the natural law interpretation of the Athenian's account of law to claim that his statement that those regimes are genuine instances of well-constituted political and legal regimes is a purely descriptive statement that reports someone else's evaluations or a 'detached' statement that reports what follows from someone else's evaluations (for detached statements see Joseph Raz, The Concept of a Legal System (Clarendon Press, 1970) 237-38). His statement expresses his own evaluative perspective though, as I explain in the main text, the relevant standard of evaluation that he relies upon is not the hierarchy of the four cardinal virtues but a more mundane political standard of social stability and political common sense. (See Finnis (n 1) 366-367 for the relevance of the distinction between evaluative, descriptive and detached statements in analysing Plato's theory of law. I depart from Finnis in understanding the relevant evaluative statements as expressing a broader range of evaluations of a political and legal regime that include reference to mundane political standards and not only evaluations from the perspective of practical reasonableness.)

${ }^{19}$ Supporters of the natural law interpretation of the Athenian's account of law may put forward the following counter-arguments. (1) They may claim that in book 3 the Athenian believes that the laws of Sparta and Crete
} 
So, the Athenian does not take the standard of politeia in a narrow sense to be a

\author{
stringent moral standard that is determined by the hierarchy of the four cardinal virtues. ${ }^{20} \mathrm{By}$ \\ the combination of political friendship, freedom and collective intellectual quality he
}

understands a more mundane political standard that could be attained even in significantly

morally flawed political and legal regimes. More specifically, he explains that the relevant

properly reflect the hierarchy of the four cardinal virtues on the basis of his claim at 630d4-7 that it may be his own and his interlocutors' inability to understand the aim of the laws of Sparta and Crete that makes them think that they only aim at the cultivation of courage. But, first, this retort does not account for the Athenian's use of the Persian empire during the reign of Cyrus and Darius and the Athenian democracy during the Persian wars as examples of politeia in a narrow sense. Secondly, the criticisms of the laws of Sparta and Crete that I refer to in the main text and that are presented after the Athenian's claim at 630d4-7 are so devastating that it is implausible to assume that in book 3 he believes that the laws of Sparta and Crete have supreme moral value. Rather it is more plausible to assume that for him the possibility that the laws of Sparta and Crete may properly reflect the hierarchy of the four cardinal virtues is a hypothesis that the close study of their institutions which he concludes in book 2 ultimately refutes (for a similar point, see S. Suavé Meyer, Plato Laws 1 and 2, Oxford 2015, 104-105.) (2) They may rely on what we may call a 'subtext argument'. They may claim that the Athenian uses morally flawed regimes like Sparta and Crete as genuine instances of politeia in a narrow sense for some dramatic purpose, and more specifically, for the sake of his interlocutors who occasionally struggle to follow his argument. A perceptive reader of the Laws, however, will surmise that he believes that only regimes that properly reflect the hierarchy of the four cardinal virtues are genuine instances of politieia in a narrow sense. But, on the one hand, this kind of subtext arguments should be a last resort once every other means of interpreting a difficult text has been exhausted. As I explain in the main text, there is an interpretation of the Athenian's claim that regimes like Sparta and Crete are genuine instances of politeia in a narrow sense that takes his claim at face value. On the other hand, it is unclear what dramatic purpose would be served by failing to take the Athenian at his word. The Athenian has already explained to his interlocutors that the morally good laws should properly reflect the hierarchy of the four cardinal virtues (631c1-d7). If his view were that only regimes whose laws properly reflect the hierarchy of the four cardinal virtues were genuine examples of politeia in a narrow sense and he nevertheless used as examples significantly morally flawed regimes, he would create only confusion to his interlocutors (and to the readers of the Laws).

${ }^{20}$ One may suggest that the evaluative standard of politeia in a narrow sense is an objective moral standard which is nevertheless less stringent than approximation to the hierarchy of the four cardinal virtues (I am grateful to an anonymous referee for that suggestion). But what might that mundane moral standard be? I see three main possibilities. First, one may take politeia in a narrow sense to aim at (even though it may ultimately fail to approximate or express) the hierarchy of the four cardinal virtues. But this interpretation directly conflicts with the evidence I mentioned in the main text. Sparta and Crete aim at the wrong hierarchy of the four cardinal virtues and Persia during the reign of Cyrus and Darius and Athens during the Persian wars aim at material goods as opposed to virtue. Second, one may treat the combination of freedom and subordination that a politeia in a narrow sense promotes to be a mundane moral standard. But, as I explain in the main text, the way the Athenian describes that standard suggests that he considers its basis to be some political compromise of perceived political interests of rulers and subjects and does not reflect anything like appreciation of the moral value of autonomy or the moral value of subordinating to authorities. Furthermore, it may take a multiplicity of forms as diverse as an Athenian democracy and a Persian monarchy and so it is hard to identify a potential common moral ground that those forms may share. Third, one may consider politeia in a narrow sense to exhibit some minimal moral qualities such as a degree of self-constraint in the pursuit of one's perceived interest or a degree of disinterested concern for the well-being of one's fellow citizens. But, on the one hand, as I explain more fully in section 4, the Athenian considers such qualities to be merely 'demotic virtues'. Demotic virtues lack any moral significance unless they are guided by the virtue of wisdom, that is, unless they are guided by proper understanding of the hierarchy of the four cardinal virtues (see also $n$ 49). And, on the other hand, those demotic virtues may be treated on a par with what Hart labelled the 'minimum content of natural law' (see n 6). Their presence may be a precondition for the existence of a legal and political order but they are compatible with significant immorality. 
standard is the result of the prevalence in a political community of an ideology that allows for some compromise between the political value of the freedom (to eleutheron, 693e5) of the subjects and the political value of their subordination (douleias, 694a4) to the rulers (693d2694a1). By 'freedom' the Athenian does not primarily understand the absence of state intervention into the private affairs of the subjects. Rather, he understands some form of political empowerment of the subjects. ${ }^{21}$ His account of Sparta's constitution (691d8-692b1) and Cyrus' reign (694a3-b6) suggests that he has primarily in mind the right of the subjects to hold in some way the rulers accountable or to participate to some extent in political decisionmaking. For a genuine instance of politeia in a narrow sense to exist, the political empowerment of subjects, however, needs to be mixed with respect for the authority of rulers and laws, so as to avoid the anarchy that characterised the Athenian democracy after the Persian wars (701b5-c5). If a constitution does not mix in any way (see ameiktous at 693b3) the values of the political empowerment and subordination, it will fail to satisfy the relevant standard (693b1-5).

The political regimes that the Athenian takes to exemplify the standard of politeia in a narrow sense differ significantly in the way that they combine the values of freedom and subordination. For example, Cyrus’ and Darius’ regimes were considerably more authoritarian than the Athenian democracy during the Persian wars. So, for the Athenian in order for a regime to be a genuine instance of politeia in a narrow sense, it suffices that it combines in some way or to some extent the values of freedom and subordination and it is not necessary that it satisfies a specific combination of those values.

\footnotetext{
21 This becomes clear by the fact that the opposite of freedom is subordination (douleia, which literally means slavery). The Athenian does not specify the minimal amount of political empowerment that the subjects need to possess in order for a regime to be validly considered a genuine instance of politeia in a narrow sense. As I later explain, he describes, however, a paradigmatic case of a regime in which the subjects lack any meaningful sense of political empowerment. It is a factional regime in which the rulers believe that they have a natural entitlement to rule because they are stronger than their subjects (see section 3.4).
} 
In a similar manner, the collective intellectual quality that the citizens of genuine instances of politeia in a narrow sense possess is not cognitive excellence that is equivalent to wisdom understood as the highest of the four cardinal virtues. Rather it is ordinary common sense that enables rulers and subjects in a regime to reach a political compromise that reflects some combination of the values of freedom and subordination. ${ }^{22}$ And 'friendship' denotes the social cohesion reached as a result of that compromise and need not be based on genuine virtue. $^{23}$

Since a genuine instance of politeia in a narrow sense has an order due to law I translate it as 'political and legal order' ${ }^{24}$ Law alongside with the administrative actions of its rulers and its overall education and culture serve its specific combination of the values of political empowerment and subordination, that is, its specific political ideology. ${ }^{25}$ For example, during the reign of Cyrus and Darius, the political ideology of the Persian regime was supported by a range of laws and administrative actions of its rulers (like laws and policies protecting some freedom of speech and the right of at least some subjects to advise on political issues) (694a2-b6 and 695c6-d5).

To recapitulate, it is not part of the meaning of politeia in a narrow sense that its laws (alongside with its policies, overall education and culture) express or approximate the hierarchy of the four cardinal virtues. For a political and legal order to exist it suffices that its laws express political common sense that enables a combination of the values of freedom and

\footnotetext{
${ }^{22}$ So the Athenian uses 'wisdom', 'soundness of mind' and 'reason' to denote ordinary levels of intellectual accomplishment that may be attained by ordinary people and not exceptional intellectual excellence attained, for example, by members of the Nocturnal Council. As I explain in section 3.2, he has specifically in mind civic enkratic reason that involves judgements about the long-term political consequences of different public policies (see also $n$ 36).

${ }^{23}$ This kind of political friendship may be understood as a species of what Aristotle describes as utilitarian friendship (Nicomachean Ethics 8.3, 1156a10-12) and is based on common political advantage.

${ }^{24}$ It is not clear whether the Athenian believes that more than one legal system may co-exist in the same political order or whether a legal system may belong to more than one political order.

${ }^{25}$ The role of education and culture in promoting political ideology is vividly depicted in the Athenian's account of the Athenian democracy at 700a7-701b4.
} 
subordination to prevail and generates an adequate degree of social stability in a regime. Of course a political and legal order may be further evaluated to determine whether its laws express the hierarchy of the four cardinal virtues. That is precisely what the Athenian does when he examines the moral credentials of the laws of Sparta and Crete in the first two books of the Laws. But this substantive moral evaluation of a regime is different from the evaluation in which he engages in book 3 in order to determine whether a regime is a political and legal order or else a genuine instance of politeia in a narrow sense.

I further elucidate the standard of political and legal order as understood by the Athenian in sections 3.2 to 3.5 and in section 4. But first I turn to discussing the main textual evidence in support of the natural law interpretation.

\section{LAW, REASON AND AKRASIA}

\subsection{The main textual evidence for the natural law interpretation}

Supporters of the natural law interpretation of Plato's account of the nature of law as presented in the Laws primarily rely on two passages of book $4 .{ }^{26}$ The first passage is part of the Athenian's discussion of the political arrangements of the mythological age of Cronus. During that period human affairs were administered by spirits who were a superior species to humans. As a result, human society enjoyed peace, self-restraint, rule of law (eunomian), plenty of justice, and the type of happiness generated by the absence of faction (713e1-3). ${ }^{27}$ The story about the age of Cronus illustrates the following point:

\footnotetext{
${ }^{26}$ See the works cited in note 1 . In the main text I reconstruct the basic points of the natural law interpretation. ${ }^{27}$ I follow Rowe (n 1) 41 in taking the Athenian to mean that during the age of Cronus human beings were not fully happy but only happy to the extent that they were free of faction.
} 
T4. '[A]...those cities that are governed not by god but by humans can never be free from evil and pain. But the upshot is that we should all imitate in every manner the so-called life during Cronus' age and obey whatever in us partakes of immortality both in public, in the governance of cities, and in private, in the administration of our homes, calling 'law' (nomos) the distribution (dianomê) of reason (nous). [B] But there is no prospect of salvation, as we have just said, whenever a single individual or an oligarchy or a democracy with a soul that is motivated by pleasures and the satisfaction of desires, that needs to be filled by those and that is unable to contain its lust but is rather sick with a never-ending and overwhelming disease rules a city or [whenever such a soul rules] an individual destroying the laws.' (713e4-714a2)

\section{The second passage comes after T4 and elaborates on its conclusion:}

T5. '[A] When there is fight about the ruling offices those who prevail totally monopolize power in the city and do not allow the losers and their descendants to occupy any political office; both parties live their lives guarding closely each other because they fear that someone motivated by memories of the past wrongs might get into office and start an uprising. Of course we say that those are not political and legal orders (politeias) and that the laws which are not promulgated for the sake of the whole city are not correct laws (out' orthous nomous). When they are promulgated for the sake of some, we say that their authors are factionaries and not citizens and that they speak in vain when they call what they promulgate '[political] justice' ${ }^{28}$ We say those things for the following reason, namely, in order to explain that in your city [i.e. Magnesia] we should not give political power to anyone because he is rich or because he possesses any of the following, strength, or size or good birth. [B] Rather we say that he who is most obedient to the posited laws and wins that victory in the city should be given the service of the gods; the greatest service should be given to the first and the second to the second rank in that service and so on the remaining services should be allocated. Those who are now called rulers I called 'servants of the laws' not in order to invent new names but because I believe that the salvation of the city and its opposite depend more on that than anything else. For this city in which law is subordinate and lacks authority (akuros) I consider it to be ready for collapse; while in the city in which the law is the master (despotês) of the rulers and the rulers are slaves to the law I see salvation and the production of all the goods that the gods gave to the cities.' (715a8-d6)

According to the natural law interpretation, in T4A the reason (nous) with the distribution, that is, the conclusions, of which the Athenian identifies legal norms is equivalent to what I call 'substantive moral reason’. Substantive moral reason involves knowledge of the hierarchy the four cardinal virtues (631c5-d2 and 688a6-b4). It also involves high-level philosophical understanding of the common element that makes them all

\footnotetext{
${ }^{28}$ According to the factionaries' principle of political justice, they have a natural entitlement to rule because they are stronger than their subjects (714b3-715a4). The Athenian has classified the thesis that the stronger have a natural entitlement to rule as one of the seven common claims to authority (690b4-8). On the natural law interpretation in T4A he denies that that claim to authority is a valid principle of political justice because it does not accord with the precepts of substantive moral reason. For my interpretation of the Athenian's reason for denying that the factionaries' claim to rule is a valid principle of political justice see section 3.4 and n 41 .
} 
virtues (965c9-d7). It amounts to the highest virtue of wisdom (phronêsis) (631c5-7) and is possessed by the true political expert (875c4-d5) and the members of the Nocturnal Council that rules Magnesia (963e5-966b8). So, in T4A legal norms are identified with objective moral norms as specified by substantive moral reason that involves high-level philosophical knowledge of the four cardinal virtues.

T5A is understood in the light of T4A. The conception of the good of the whole city that the Athenian refers to is 'morally laden': it is the common good as specified by substantive moral reason. Since the factionaries in T5A are not guided by substantive moral reason, they fail to legislate in accordance with the hierarchy of the four cardinal virtues and thus they fail to promote the common good. For that reason their regimes are not political and legal orders or else genuine instances of politeia in a narrow sense. This means that regimes that fail to promote the common good as specified by substantive moral reason are not legal systems or at least they are deficient qua legal systems.

This understanding of what makes a regime a political and legal order conflicts with the conception of politeia in a narrow sense as analyzed in book 3. For, as I have already explained, in book 3 the Athenian classifies as political and legal orders regimes whose norms of public conduct fail to reflect the hierarchy of the four cardinal virtues and are indeed significantly morally flawed. Should we assume that in T5A the Athenian has shifted to a different conception of politeia in a narrow sense? This is implausible. For, in book 4, just two Stephanus pages before T5A, he reaffirms the conception of politeia in a narrow sense that he articulated in book 3: he claims that Sparta and Crete are genuine instances of politeia in a narrow sense (ontôs ...politeiôn metechete, $712 \mathrm{e} 9$ ). ${ }^{29}$

\footnotetext{
${ }^{29}$ At 712e9 the Athenian states his own evaluation of the merits of Sparta and Crete qua political and legal orders and does not report his interlocutors' corresponding evaluations or what follows from them. The Athenian's claim that Sparta and Crete are political and legal orders purports to overcome his interlocutors'
} 
If, then, in book 4 the Athenian continues to operate with the conception of politeia in a narrow sense that he articulated in book 3 , the natural law interpretation fails to correctly account for the distinction that the Athenian draws in T5A between, on the one hand, factional regimes and, on the other hand, genuine instances of politeia in a narrow sense. Whatever disqualifies factional regimes from being genuine instances of politeia in a narrow sense cannot be that their norms of public conduct do not accord with specifications of substantive moral reason. For neither do the norms of public conduct of genuine instances of politeia in a narrow sense like Sparta and Crete.

More generally, the fact that in book 4 the Athenian continues to operate with the conception of politeia in a narrow sense articulated in book 3 shows that for him the constitutive aim of political and legal orders is not to approximate the hierarchy of the four cardinal virtues (though it may be their appropriate moral aim). It also invites for an interpretation of T4A and T5A that makes the constitutive aim of political and legal orders consistent with the account of the standard of politeia in a narrow sense that the Athenian provided in book 3.

Further uneasiness with the natural law interpretation is generated by the fact that it does not quite square with the natural reading of the points made in T4B and T5B. In T4B the described danger to any city, irrespective of its form of government, is not that it is ruled by laws that fail to reflect the hierarchy of the four cardinal virtues. Rather the danger is that the rule of law collapses and that a city is ruled instead by the uncontrollable desires of its rulers. A similar point is made in T5B in which the Athenian stresses that the salvation of cities

\footnotetext{
inability to classify those regimes using as point of reference their contemporary aristocratic, democratic and tyrannical regimes (711d2-e8) (cf. n 18). Furthermore for reasons I have already explained (see n 19) he cannot believe that the laws of Sparta and Crete properly reflect the hierarchy of the four cardinal virtues.
} 
depends above all to the observance of the rule of law by the rulers. ${ }^{30}$ So, T4B and T5B focus on the danger generated by the law's lack of effective authority over the rulers and not by the absence of laws that are correct specifications of the true moral values.

Thus, we need an interpretation of T4A and T5A that preserves their continuity with T4B and T5B respectively and allows for significantly morally flawed political arrangements to count as political and legal orders or else genuine instances of politeia in a narrow sense. In what follows I propose such an interpretation.

\subsection{Law as enkratic reason}

The kernel of my proposed interpretation is that in T4A the Athenian reiterates his original definition of law as calculation. In book 1 of the Laws, he claims that apart from anticipations of pleasures and pains, which oppose each other and are non-rational (644c6-7) there is in us 'calculation about which of these [i.e. the pleasures and pains] are better or worse that, when it becomes comes common belief of the city, is called "law".' (644d1-3). He illustrates the function of calculation with the so-called 'puppet image':

T6. .... Let us consider that each of us, though we are living creatures, is a divine puppet that is constructed either as a plaything for the gods or for some serious purpose. For of course we do not know the latter but we do know this thing, that these states of ours that are in us like nerves or strings both pull us and, since they are opposite to each other, pull against one another towards opposing actions that cross the line between virtue and

\footnotetext{
${ }^{30}$ The Athenian's reference to 'the production of all the goods that the gods gave to the cities' at 715d6 (the last line of T5B) does not indicate that he has in mind morally good laws that may produce extra goods to the city beyond the goods associated with the existence of a social order secured by the rule of law. For example, the Athenian need not refer to goods similar to the goods produced by the laws of the spirits (713d5-e3). As T4A makes clear, human societies can never reach the level of happiness attained during the rule of the spirits but toil and evil will always be present. By 'gods' at 715d6 the Athenian must be understood to refer to the laws in line with his previous point at $715 \mathrm{c} 2-\mathrm{d} 1$ that the servants to the gods are the servants to the laws. Thus, at $715 \mathrm{~d} 6$ he simply refers to the benefits of the rule of law, for example, safety and political friendship (based on a compromise of the political interests of rulers and subjects (see section 3.4)), which he previously described in his account of Sparta, Crete, the Persian empire during the reign of Cyrus and Darius and the Athenian democracy during the Persian wars in book 3.
} 
vice. ${ }^{31}$ For, as the argument goes, each one of us should pull against the other cords while he always follows one of those pulling forces and never abandons it: this is the golden and sacred directing-cord (agôgên) of calculation (logismos), which is called (epikaloumenên) the public law of the city. Since it is golden, it is soft, while the other cords are hard and iron and resemble a whole variety of other forms. One should always cooperate with the finest directing-cord, namely, that of the law. For since calculation is fine but mild and not violent, its directing-cord needs assistants so that the golden kind in us wins over the other kinds. And in this way the tale about virtue that we are really puppets would hold its point, and in some way it would become clearer what it means to be superior and inferior to oneself; ${ }^{32}$ and also concerning a city and an individual [it would become clearer] that, on the one hand, the individual, once he grasps the true account about the pulling forces in himself, must live his life following it, and on the other hand, the city, after it receives an account either by some god or by that individual who has grasped those things, makes law and must arrange its internal affairs and its affairs with the other cities in accordance with law. ${ }^{33}$ (644d7-645b8)

On the standard interpretation of T6, the puppet image explains how akrasia and enkrateia are psychologically possible. ${ }^{34}$ The iron cords that oppose the soft cord of reasoning represent the agent's non-rational desires for pleasure and the avoidance of pain (644c6-d1). When the agent follows one of the iron cords, he acts akratically. When the softcord of calculation prevails, he behaves enkratically.

\footnotetext{
${ }^{31}$ The Athenian's point is that whether we will behave virtuously or not ultimately depends on which of the two types of strings, calculation or non-rational desires, guides our action. He does not subscribe to the view that, if our actions follow our calculation, they are necessarily good. Rather he believes that being guided by calculation is necessary, though not sufficient, for virtue (see, $\mathrm{n} 32$ ).

32 The Athenian claims that the dialectical purpose of the story that we are puppets is to explain to Cleinias and Megillus through an image (644b9-c2) the thesis that 'those who are able to rule over themselves are good while those who are not are bad' (644b6-7). He considers that thesis to summarize the commonly accepted conclusion (see sunechorêsamen, 644b6) of a previous discussion of what it is for individuals or cities to win over or to be defeated by themselves. The Athenian, however, did not accept that victory over oneself at individual or civic level is equated to virtue. At most he accepted that it is a necessary, though not sufficient, condition for virtue (see 628d1). So, he must take the tale about virtue that the puppet image illustrates to be that no individuals or cities can become virtuous unless their actions are guided by calculation instead of non-rational desires. This tale about virtue is of course compatible with the possibility that individuals or cities that are guided by calculation fail to be virtuous. Admittedly, the Athenian does not use precise language and the puppet image passage may allow the impression that victory over oneself is equated to virtue. The imprecision may be deliberate for at this stage of the discussion the Athenian may not want to complicate the argument with his interlocutors who both understand virtue as victory over oneself (which ultimately amounts to an equation of virtue with enkrateia). For an illuminating discussion of the dialectical context of the puppet image that accounts for the Athenian's deliberate imprecision, see Suavé Meyer (n 19) 161-63.

${ }^{33}$ The true account that an individual or a city receives is the tale about virtue that the Athenian purports the puppet image to illustrate, namely, that being guided by calculation is necessary for virtue (see, $n$ 32).

${ }^{34}$ For an excellent philosophical analysis of the standard interpretation to which I am indebted see Christopher Bobonich Plato's Utopia Recast (Oxford University Press 2002) 260-67. The standard interpretation has been recently challenged by C Wilburn 'Akrasia and Self-Rule in Plato's Laws' (2012) Oxford Studies in Ancient Philosophy 43 26. For some telling criticisms against Wilburn's challenge see Suavé Meyer (n 19) 163.
} 
The judgements that the agent reaches as a result of calculation are judgements about which of the opposing future pleasures and pains are good for the agent. Given that calculation involves comparisons of the relevant pleasures and pains, the judgements that the agent reaches as a result of calculation must be about what is overall good for the agent. ${ }^{35}$ But they need not express what is objectively overall good for him. The Athenian acknowledges that mistaken judgements about what is overall good for one may effectively control one's non-rational desires. Some people are able to control their own desires for pleasure and are masterful in techniques about how to tempt others though they are entirely bad (635d2-4). If they are entirely bad, then, given the close link between virtue and happiness that the Athenian accepts (660e2-661d5), they are not guided by judgements that express what is objectively overall good for them. Rather it is their false beliefs about what is overall good for them that succeed in controlling their desires.

Law is defined as calculation about what is overall good for the city. In line with the Athenian's genealogy of law, the relevant calculation must be that of a lawgiver. But it does not suffice for law to exist that a lawgiver forms a judgement about the long-term political consequences of different types of public conduct. The relevant judgements must become the common belief of the city, that is, they must be accepted by both rulers and subjects. So, law does not merely express conclusions of the deliberation of a single individual but conclusions of what we may call 'civic reason'. ${ }^{36}$

\footnotetext{
${ }^{35}$ See Bobonich (n 34) 263-66.

${ }^{36}$ The shift from 'calculation' (logismos) in T6 to 'reason' (nous) in the definition of law in T4A is not problematic. On the one hand, the Athenian uses 'reason' to refer to the generic rational faculty in which some animals and especially the human beings share (672c1 and 737b4). This may be understood as the innate faculty to be guided by rational considerations about what one perceives to be in one's overall best interests as opposed to brute instincts. In this generic sense, 'reason' has a function similar to the function of calculation as described in T6. On the other hand, the Athenian uses 'reason' to describe cases of both individual and civic enkrateia. First, he claims that no joint activity, for example, the activity of procreation, can produce good results, say, healthy offspring, unless each participant has reason (echontes noun) and acts in accordance with it (783e1-4). The Athenian's point is clearly not that in order to produce healthy offspring married couples in Magnesia need to possess substantive moral reason (like the members of the Nocturnal Council). Rather he means that they must be able to understand that some practises, for example, consumption of alcohol, may affect the quality of
} 
The analogy of law with the calculation of an individual suggests that law is identified with conclusions of enkratic 'civic' reason. As the judgements of the calculation of an individual about what is overall good for him differ from his non-rational desires, so law differs from relevant non-rational desires. The latter may be twofold. On the one hand, law may contravene the desires of the citizens for some perceived short-term collective political benefit. On the other hand, law may contravene the desires of the citizens for some perceived short-term or long-term individual benefit whether political or private. Insofar as the latter desires are about long-term benefits they may be rational from the perspective of the individual agent, that is, in agreement with conclusions of enkratic individual reason. But they are non-rational from the perspective of enkratic civic reason. This creates a conflict between enkratic individual reason and enkratic civic reason which I will discuss shortly.

The analogy of law with the calculation of an individual also suggests that law is identified with what the lawgiver proclaims and the city accepts to be overall good for it and not with what is objectively overall good for it. This means that law as enkratic civic reason may prescribe immoral practices that are ultimately objectively overall bad for the city. So, if in T4A the Athenian simply repeats his initial definition of law as conclusions of calculation the function of which T6 elucidates, ${ }^{37}$ then he can validly consider regimes like Sparta and Crete whose laws are significantly immoral to be political and legal orders.

the foetus and relatedly constrain their sexual desires, for example, avoid having sex when drunk (775b4-e4). Secondly, he also claims that the Persian empire during the reign of Cyrus was governed by a 'community of reason' (koinônia tou nou) since Cyrus allowed anyone considered to be wise to give counsel on public issues (694b1-6). The advice of Cyrus' counsellors promotes the ends of Cyrus' regime which, as I have explained, are materialistic and not moral and thus are not guided by substantive moral reason. Rather, Cyrus' counsellors offer reasoned advice about how his empire would expand its territory or become wealthier that is not marred by their blind political ambitions. So, the Athenian's point is that Cyrus' empire was ruled by enkratic civic reason. ${ }^{37}$ On my interpretation the gist of T4A may be understood as follows: in the absence of divine rule and given the frailty of human nature, we should be ruled not by human rulers but by enkratic civic reason; in so doing we imitate life under Cronus by being guided by something immortal like the spirits, namely, reason. 


\subsection{Enkrateia and the rule of law}

As I have already mentioned, enkratic civic reason and enkratic individual reason may conflict. T6 explains that the conflict is resolved in favour of enkratic civic reason. Since the cord of calculation in an individual is by nature weaker than the iron cords of his non-rational desires, it needs the external assistance of public law in order to effectively control them. So, unless one accepts the authority of law, one cannot be enkratic.

Does it follow that it is rational for one to accept the authority of law? Two additional assumptions are needed. First, other things being equal, one is more likely to advance one's perceived long-term interests by being enkratic than by being akratic. The Athenian's claim in T6 that the enkratic agent is superior to oneself and the characterisation of the person who is ruled by his non-rational desires in T4B as sick suggest that he makes that assumption. Second, by subordinating to law one can still achieve at least some of one's perceived longterm interests other than avoiding the sanctions for breaking the law. For if by subordinating to law one does not satisfy any of one's perceived long term-interests, then the perceived benefit that one might get by occasionally breaking the law may outweigh the harm resulting from the relevant sanctions for breaking the law or there may be no difference between the two. As I explain in the next section, the Athenian also makes the second assumption, since he believes that in order for law to exist there must be some compromise of the perceived political interests of rulers and subjects.

So, in a nutshell, the Athenian believes that it is rational for one to accept the authority of law because one is more likely to satisfy at least some of one’s perceived longterm interests by subordinating to law than by relying on the power of one’s own reason to control one’s desires for short-term benefits. 
How does public law help an individual remain enkratic? First, as we have seen in section 2, law is backed by sanctions. Fear of externally imposed sanctions provides individuals with strong incentives to control their desires for some short-term political or private benefit. Secondly, apart from fear of sanctions, law also triggers the fear of acquiring a bad reputation before our fellow citizens for failing to say or do something fine. The Athenian calls this fear 'shame' (646e10-647a2). In his account of the Athenian democracy during the Persian wars, he identifies a particular type of shame that we may call 'civic'. Civic shame both is the product of law (699c2-4) and in turn produces a law-abiding disposition (698b6). Law produces civic shame because it identifies the object of civic shame, that is, it identifies certain norms of public conduct as fine or disgraceful (728a5-7). Those are norms which the agent fears that he may be criticized by his fellow-citizens for failing to adhere to. Civic shame supports the rule of law in the following way: once it is instilled in people, it helps keep under control their desires for self-aggrandisement that may tempt them to break the law.

It is necessary for the rulers in particular to subordinate to law if they are to remain enkratic. The Athenian is greatly pessimistic about the ability of the golden cord of calculation in any individual to consistently control the iron cords of his various desires when he acquires absolute power. ${ }^{38}$ Even if someone has exceptional intellectual abilities and is able to understand that his personal overall good is best served only when the good of the city is also served (875a5-b1), he should not be allowed to act on his political knowledge and rule the city. The reason is that his mortal nature (thnêtê phusis, 875b7) will prevent him from sticking to the truth about the congruence of his personal interest and the interest of the city

\footnotetext{
${ }^{38}$ With the exception of that extremely rare species, the political expert who could control by the power of his own reason his desire for self-aggrandisement (see T2). The case of the true political expert does not significantly affect the scope of the Athenian's pessimism because he takes such an individual to be extremely rare.
} 
and his non-rational (see the use of alogôs at 875b8) desires for self-aggrandisement (pleonexian kai idiopragian, 875b6-7), which in this context should be understood as desires for short-term benefits, will get the best of him (875b1-7). The only solution is for him to be ruled by law. Other things being equal, the fear of sanctions if he transgresses the legal boundaries of his authority and civic shame are more likely to keep his non-rational desires under control than his reason.

How does the Athenian understand the rule of law? First, his contrast between the rule of a statesman and the rule of law suggests that for him when law rules the specific executive and judicial decisions of the rulers must be guided by the general (albeit, as explained in section 2.2, epistemically deficient) laws. This means that the rulers must consistently apply the laws. Secondly, his identification of law with conclusions of enkratic civic reason suggests that laws should be to a great extent internally consistent and significantly stable, that is, they should not change with a great degree of frequency based on the rulers' desires for short-term benefits.

For the Athenian the rule of law and the rulers' enkrateia are interrelated. As we have seen, he believes that, unless law has effective authority over the rulers, they will become akratic agents. T4B and T5B show that if they are akratic, they will not be able to sustain a political order in which the rule of law prevails. In T4B the Athenian claims that akratic rulers destroy the laws. And in T5B he claims that a city in which law lacks effective authority over the rulers is ready to collapse. His line of reasoning can be easily reconstructed. The norms of public conduct established by akratic rulers express the chaotic and conflicting nature of their non-rational desires. They tend to be inconsistent with one another, to change with unpredictable and confusing frequency and to be implemented erratically. Like the Persian despotic rulers the Athenian refers to in book 3, akratic rulers are 
likely to cause rowdy disorder (anastatous) in their states moved by desires for even the slightest short-term benefit (697d4-6).

By contrast, if a city is to enjoy political stability, the rulers must be servants to the laws. This means that the rulers' respect for the rule of law is necessary for the existence of a political and legal order.

Bringing together the points about the nature of law that the Athenian makes in T4, T5 and T6 I suggest that the definition of law he operates with may be formulated as follows:

Law is identified with norms of public conduct that express conclusions of enkratic civic reason, that is, (a) views of a lawgiver about what is overall good for the whole city which (b) have been accepted by the subjects and (c) have effective authority over the rulers.

\subsection{Law and the good of the city}

Conditions (b) and (c) show that in order for law to fulfil its role as guardian of the enkrateia of the city it needs to have effective control over both rulers and subjects. Given the power of people’s desire for self-aggrandisement, how can systematic abuses of law by the rulers or continuous evasions of laws by the subjects be avoided? Law’s authority cannot ultimately depend on people's good will but the threat of legal punishment needs to be credible and the sense of civic shame strong. ${ }^{39}$ The Athenian's way out of this conundrum is to ultimately ground the rule of law in a compromise between the conflicting political interests of rulers and subjects. As we have seen, for the Athenian a legal and political order can only exist when there is some combination of the value of the political empowerment of the subjects and the value of their subordination to the rulers. This means that the subjects need to have at least some political power so as to prevent systematic deviations from the rule of law by the

\footnotetext{
${ }^{39}$ The Athenian castigates the naivety of legislators who think that they can secure the rulers' commitment to the rule of law by making them take an oath (692b3-6).
} 
rulers and the rulers need to retain sufficient political power to prevent anarchy. The rule of law can obtain only if those political conditions are met.

The importance that the Athenian ascribes to the political compromise between rulers and subjects helps explain why the factional regimes in T5A and the Athenian democracy after the Persian wars are not political and legal orders and why it is necessary for law to express judgements about what is overall good for the whole city. On the one hand, factional rulers believe that they have a natural entitlement to absolute rule because they are the stronger (714c1-d10) ${ }^{40}$ and subsequently deprive their subjects of any political power. As a result, their regimes fail to satisfy one political condition necessary for the existence of the rule of law, namely, the (even minimal) political empowerment of the subjects. Furthermore, factional rulers behave acratically as they are in a rather neurotic state filled with constant fear of possible counter-revolutions. It is unlikely that they can resist the temptation to break their own norms of public conduct when they suspect a plot against them or to endlessly revise them as they try to address multifarious real or imaginary threats to their power. At the other extreme, the citizens of Athens after the Persian wars showed extreme liberality and rejected any authorities including law (701b5-c4). So, their regime failed to satisfy another necessary condition for the existence of the rule of law, namely, the presence of effective government.

On the other hand, for the rule of law to obtain the political compromise between rulers and subjects must be expressed in the norms that the lawgiver promulgates. This idea is captured in condition (a) of the Athenian's definition of law. Contra the natural law interpretation, the good of the whole city that laws purport to promote is not the common good as specified by substantive moral reason. Rather it reflects the compromise between the

\footnotetext{
${ }^{40}$ Cf. n 28.
} 
political interests of rulers and subjects that enables a regime to attain an adequate level of political stability. It is that political compromise which the Athenian has described at various points in book 3 as the prevalence of political friendship and political common sense and which characterises all genuine instances of politeia in a narrow sense (see section 2.4). Furthermore, since that political compromise enables the rule of law to obtain, in contrast to the principle that the stronger should rule by nature it may generate a functional principle of political justice, that is, a principle of political justice that can sustain a political and legal order. $^{41}$

The Athenian's argument relies on the assumption that only the political empowerment of the subjects may effectively constrain the political power of the rulers so that the rule of law be preserved. One could object that the rule of law may be preserved in an exploitative regime in which the ruling class through separation of powers imposes constrains on the political power of its members in order to preclude that one of them acquires supreme power. In that case the exploitative oligarchs may adhere to the rule of law while pursuing only the perceived long-term interests of their own class and totally disregarding the interests of their subjects.

The Athenian’s account of the separation of political powers in Sparta (691d8-b7) suggests that for him anything short of some political empowerment of the subjects is unlikely to preserve the rule of law. He claims that the original division of powers in Sparta between the dual kings and the aristocratic senate (gerousia) failed to engender political

\footnotetext{
${ }^{41}$ So, as per T5A, the factionaries speak in vain when they say that their claim to rule is a principle of political justice not because their claim is incompatible with the principles of substantive moral reason but because it is incompatible with the rule of law and thus unable to sustain a political and legal order (cf n 28).
} 
stability. Political stability was achieved only after the popularly elected ephors put an end to the systematic abuses of power of the previous oligarchic political arrangement (692a3-6). ${ }^{42}$

We may take the Athenian to reason as follows. ${ }^{43}$ Oligarchs who totally disregard the interests of their subjects may have strong incentives (that is, fear of punishment and civic shame) to uphold the norms that regulate their conduct towards their fellow rulers. But given the frailty of human nature, if their power remains unchecked by their subjects, their individual and collective commitment to consistently conform to norms regulating their conduct towards their subjects will be impaired. Desires for short-term collective or individual benefits or real or imaginary fears of possible revolts by the oppressed subjects will eventually lead them to break, revise, or apply erratically the relevant norms in ways that may ultimately hinder or totally frustrate their perceived long-term political interests. Given that norms regulating their conduct towards their subjects form an important and arguably the largest body of norms of public conduct, in their regime there will be significant collapse of the rule of law. For the Athenian political common sense recommends that, if the rule of law is to obtain, the subjects be politically empowered to some degree and relatedly constrain the political power of the oligarchs, as happened in Sparta.

\subsection{The positivist interpretation refined}

\footnotetext{
42 The Athenian speaks of the power of the kings and the senate as being 'insolent' (spargôsan, 692a4) and 'provocative' (thumoumenên, 692a4) which suggests that they were systematically abusing their power towards their subjects. He compares the power of the ephors to a 'curb-chain' (psalion, 692a5) which suggests that the purpose of the office was to help the subjects constrain the relevant abuses of power by the kings and the senate. ${ }^{43}$ I take what follows to be an argument based on political experience. This accords with the Athenian's claims that his account of law is informed by the successes and failings of historical political and legal regimes (676a1c10) and that his understanding of political matters is based on empirical observation (782d10-e1). As an empirical argument, it does not obviously show it is impossible that exploitative oligarchs may adhere to the rule of law while totally disregarding the interests of their subjects. See also section 5.1.
} 
The Athenian believes that a divinely inspired legislator (see section 2.1) will use law alongside with the education and culture of a political organisation in order to promote the hierarchy of the four cardinal virtues. But, contra the natural law interpretation, he does not take the latter to be the constitutive aim of law. For him the constitutive aim of law is to safeguard civic enkrateia which enables rulers and subjects to pursue at least some of their perceived long-term interests but which is compatible with significantly immoral political and legal practices.

Consequently, for the Athenian to identify law one need not morally evaluate the content of the norms of public conduct of a particular regime and examine whether they promote virtue or the common good as specified by substantive moral reason. Rather, one needs, on the one hand, to ascertain certain social facts, for example, whether a norm has been promulgated by a legislator, agreed to by the rulers and observed by the subjects and, on the other, to evaluate whether the relevant system of norms satisfies the standard of politeia in a narrow sense. T4 and T5 clarify that for that standard to be met the rule of law needs to obtain. They also identify the political conditions which make the rule of law viable.

Two questions remain. First, what philosophical motives does the Athenian have in taking the standard of politeia in a narrow sense to be promotion of civic enkrateia instead of approximation of the hierarchy of the four cardinal virtues? His preferred standard means that he analyzes law from the broad viewpoint of an ordinary planning agent who is primarily concerned with the service of his perceived long-term interests and not from the narrow viewpoint of someone who is concerned with moral perfection. The broad perspective better accounts for the importance of law as a pre-condition of human planning agency in general, that is, not only for acquiring virtue but, for developing and executing more mundane longterm plans without being side-tracked by desires for short-term benefits. And it has a wider 
explanatory scope as it is more attentive to the concerns of law-abiding rulers like Cyrus who, as I explain in section 4, was motivated primarily by self-interested considerations and not by other-directed motives. ${ }^{44}$ Correlatively, the broad viewpoint makes his argument about the importance of respecting the rule of law appealing to a wider audience. Aspiring rulers are more likely to be convinced to become law-abiding by arguments about the importance of the rule of law for the promotion of their long-term political interests than by considerations of moral perfection.

The second question concerns how the Athenian understands the significance of the rule of law. I explore his views in the next section.

\section{THE SIGNIFICANCE OF THE RULE OF LAW}

\footnotetext{
${ }^{44}$ Finnis ((n 1) n 37 at 15) claims on the basis of two passages from the Republic (3.408d-409e and 9.582a-e) that for Plato 'the lover of wisdom can understand the concerns of men of other character, while the converse does not hold; in other words the concerns and understanding of the mature and reasonable man provide a better empirical basis for the reflective account of human affairs'. (italics in the original). Finnis relies on this insight in order to establish the superiority of the viewpoint of practical reasonableness over any self-interested practical viewpoint as the central case of the legal viewpoint. Should we then think that in the Laws the Athenian would similarly find the viewpoint of someone who aims at moral perfection as more explanatorily powerful than the perspective of someone concerned with his long-term planning ability? I have already urged caution against using the evidence of the Republic in order to explain the Athenian's views on law. But even if we disregard that methodological constraint, the evidence of the Republic that Finnis cites fails to support his conclusion. For in those passages Plato does not claim that the perspective of someone with a philosophically inclined nature makes him attentive to the concerns of people of lesser moral quality. First, in the passage of book 9 he claims that the lover of wisdom has some experience (empeiria) of pleasures associated with profit and with honour while the lovers of money and fame have no experience of intellectual pleasures. But, on the one hand, it is doubtful whether the mundane experiences of the lover of wisdom make him particularly attentive to the concerns of people of lesser moral quality as he feels only contempt for their life choices (581e10-d5). And on the other, Plato's claim applies only to lovers of wisdom who live in corrupt states and not to the paradigmatic cases of lovers of wisdom, namely, the philosophers in the perfect state. For due to their extreme communist lifestyle the latter totally lack experience of a wide range of things including financial dealings or family life. So, their perspective would be particularly unsuited for an 'empirical basis for the reflective account of human affairs'. Secondly, in the passage of book 3 Plato claims that a good judge must be someone who has no experience (see apeiron, 409a5) of injustice but only comes to understand it late in life through some sort of abstract account after he is properly educated. So that judge lacks empirical understanding of the concerns of people of lesser moral quality. Furthermore, the point of the heavily censored education that the paradigmatically good judge, namely the philosopher in the perfect state, receives makes it psychologically impossible for him to see the point or understand the rationale of actions motivated by anything other than love of wisdom or virtue. So again there is no suggestion that he will be attentive to relevant self-interested concerns that motivate non-philosophers. He could at most achieve an abstract understanding of the condition of people of lesser moral quality which would require subtracting from his moral perspective.
} 
Does the significance that the Athenian ascribes to the rule of law show that he considers it to have inherent moral merit? Supporters of the idea that the rule of law has inherent moral merit may be understood to hold three main theses. The first concerns the moral demerit of systematic deviations from the rule of law. Those deviations are considered inherently immoral, that is, they are immoral qua deviations from the rule of law. ${ }^{45}$ The second concerns the moral function of the rule of law: the rule of law exemplifies respect for fundamental moral values like moral autonomy, human dignity or reciprocity. ${ }^{46}$ The third concerns the attitude of legal officials: for the rule of law to obtain legal officials need to be motivated by moral and not simply self-interested concerns. ${ }^{47}$

The following considerations suggest that the Athenian does not hold either of those theses.

First, the Athenian allows that systematic deviations from the rule of law may be in principle morally justified. For him the ideal political arrangement is the rule of the true political expert which is incompatible with the rule of law. This means that, even if the true political expert judges it expedient to promulgate certain norms of public conduct for his subjects, he may legitimately deviate from them whenever his political judgement favours an alternative course of political action.

Furthermore the Athenian does not subscribe to the view that that systematic deviations from the rule of law are inherently immoral even in non-ideal political regimes like Sparta or the Persian empire during the reign of Cyrus. For he does not condemn systematic deviations from the rule of law in those regimes because they prevent them from

\footnotetext{
${ }^{45}$ See for example, the discussion of the inner morality of the famous eight precepts of legality in Lon Fuller The Morality of Law (Yale University Press, 1969).

46 Ibid 38-41, 162-67.

${ }^{47}$ See Finnis (n 1) 273-74. I discuss Finnis’s views in more detail in section 5.2.
} 
exemplifying some significant moral quality. (With the exception of Magnesia no other nonideal political regime exemplifies significant moral qualities.) Rather systematic deviations from the rule of law in non-ideal political regimes are condemned because they subvert the ability of rulers and citizens to pursue either collectively or individually any mundane longterm plans (whether moral or immoral or non-moral). His point is that such deviations are inherently irrational rather than that they are inherently immoral. To think otherwise indicates failure to appreciate that the Athenian explains the value of the rule of law from a broad perspective which, as I explained in section 3.5, is particularly attentive to the considerations of self-interested agents and not from a narrow moral perspective.

Secondly, for the Athenian the function of the rule of law is to safeguard enkrateia and not genuine virtue. Even his preference for the political empowerment of legal subjects is based on relevant pragmatic considerations. The political empowerment of the subjects is the only viable political solution to the problem of akratic rulers.

One may be tempted to think that for the Athenian enkrateia is itself a moral value even though less significant than genuine virtue. But this is clearly not the Athenian's position. On the one hand, as we have already seen, he allows that one may have proper selfcontrol though one may be entirely wicked and use his art of deception to corrupt others (635d2-4). And, on the other, as I will explain shortly, he explicitly denies that enkrateia has any moral significance unless it is accompanied by wisdom.

Finally, one may suggest that the Athenian is committed to the thesis that being enkratic is always morally better than being akratic. We may understand that thesis in two ways. On the one hand, it may be taken to be equivalent to the thesis that an enkratic agent is always morally superior to an akratic agent irrespective of the degree of wickedness that the enkratic agent exhibits. But there is nothing that suggests that the Athenian is committed to 
that thesis. For example, there is nothing that suggests that he considers a ruler who is able to control his desires for short-term benefits and who, through his supreme mastery of the art of deception, manages to corrupt his city to be morally superior to an ordinary akratic citizen whose inability to control his desires simply frustrates his personal long-term plans but causes no great harm to his city. And there is no reason to think that that thesis is straightforwardly true and thus that the principle of charity of interpretation requires that we ascribe it to the Athenian. On the other, it may be considered equivalent to the thesis that, other things being equal, an enkratic agent is always an overall morally better person than an akratic agent. But again there is nothing to suggest that the Athenian considers, for example, the enkratic but totally wicked ruler who corrupts his city to be nevertheless still morally better than an akratic ruler who manages to cause an equivalent amount of evil in his society. And similarly there is no reason to think that that thesis is straightforwardly true and thus that the principle of charity of interpretation requires that we ascribe it to the Athenian. ${ }^{48}$

As I explained in section 3, we need only ascribe to the Athenian the thesis that enkrateia is better than akrasia from the point of view of ordinary human agency, namely, it is better in the sense that, other things being equal, by being enkratic one is better able to pursue one's preferred long-term plans irrespective of the moral value of those plans. That interpretation is consistent with the main gist of T6 and avoids drawing dubious conclusions about the comparative moral value of enkrateia and akrasia. For the Athenian the moral

\footnotetext{
${ }^{48}$ In a similar manner there is nothing that suggests that for the Athenian an extremely malevolent regime that is nevertheless characterised by civic enkrateia and thus respects the rule of law is morally superior to, say, an anarchic regime that fails to pursue any of its long-term malicious policies; or that for him a regime that respects the rule of law but otherwise is as morally bad as a malicious tyranny should be considered morally superior to the latter. Rather for the Athenian the moral quality of a regime depends on whether it reflects the hierarchy of the four cardinal virtues. Regimes that respect the rule of law are superior to other regimes in the sense that, other things being equal, they are more likely to achieve their long-term political plans (irrespective of the moral quality of those plans).
} 
quality of an agent's character and actions depends on the extent of which they reflect the hierarchy of the four cardinal virtues. ${ }^{49}$

Thirdly, for the Athenian the rule of law does not require that the ruling class are primarily motivated by genuine altruistic concerns for the political interests of their subjects. For example, he takes Cyrus’ primary political motive to be the accumulation of personal wealth and the expansion of his empire (694e6-695a1). ${ }^{50}$ The Athenian may be understood as suggesting that for the rule of law to obtain the rulers need only to be 'epistemically' (but not 'motivationally') guided by the political interests of their subjects. ${ }^{51}$ That is, in line with the content of the political compromise reached in their state, they should take into account the political interests not only of their class but also of their subjects when they pass or apply laws (thought of course their ultimate motive in doing so may be purely the promotion of their long-term self-interest).

Furthermore, the Athenian does not consider the type of self-control that the rulers must exhibit if the rule of law is to obtain to be a moral attitude. After he approves of the selfcontrol of Cyrus and Darius and castigates the akratic states of Cambyses and Xerxes, he concludes that possession of the relevant state of self-control is a necessary condition for

\footnotetext{
${ }^{49}$ The hierarchy of virtue entails that the moral value of any psychological state of the agent, for example, enkrateia, or attitudes characteristic of inferior virtues, like demotic courage (661e1), depends on his possession of the highest virtue of wisdom. This means that any psychological state that is not guided by wisdom has no moral significance by itself. That dependency of moral value on wisdom is different from (though related to) the so-called 'dependency thesis' according to which no ordinarily considered 'good' things (like health or wealth or beauty) or demotic virtues are beneficial for the agent if he lacks wisdom. (For a philosophically astute analysis of the dependency thesis in the Laws see Bobonich (n 34), 123-153.) I take the Athenian to be committed both to the dependency of moral value on wisdom and the dependency of goodness (in the sense of what is beneficial for the agent) on wisdom (though this is not the place to elaborate on their relation).

${ }^{50}$ Rulers like Cyrus may of course have some disinterested concerns for others (cf. $n$ 20). The point is that even though they may have some such concerns they are primarily motivated by considerations of what best serves their political interests. For example, if their perception of what promotes their political interests conflicted with their other-directed concerns, they would act on the former rather than the latter. We should note that for the Athenian Cyrus does not qualify as a morally good agent. He is excessively rich and no excessively rich person is morally good (742e5-743c4).

${ }^{51}$ I borrow the distinction between 'epistemic' and 'motivational' guidance from Scott J Shapiro 'On Hart's Way Out' (1998) 4 Legal Theory 489.
} 
anyone to be a ruler (696b1-4). But then he notes that this type of self-control is not worth much in isolation from the other virtues and one best remains silent about its value (696d410). He reasserts his claim that this type of self-control is of no real moral value in the context of his discussion of the qualities of the tyrant whose assistance to a good lawgiver is necessary if a good political order is to be established. He clarifies that it is simply a 'demotic' virtue and not the proper virtue of self-control that is always accompanied by wisdom (710a5-6). ${ }^{52}$ Rather it is based on a natural pre-disposition to control one’s desires for pleasure which manifests itself in a spontaneous manner and can be found in children and animals (710a7-8).

Why does the Athenian treat demotic self-control as being devoid of real value? Because, though it is a necessary condition for the development of all virtues, it is malleable and can support the rule of law in political orders that fail to respect the hierarchy of the four cardinal virtues. In other words, rulers with demotic self-control may be found in political orders, like Sparta, Crete, the Persian empire during the reign of Cyrus and Darius and Athens during the Persian wars, that promote significantly immoral practices and fail to make their citizens virtuous.

\section{LAW, HUMAN AGENCY AND TYRANNY}

I conclude with briefly discussing two distinctive features of Plato’s legal positivism as presented in the Laws. As this is a paper in the history of legal thought my discussion is highly selective and far from exhaustive. But I hope it highlights the relevance of Plato’s views to central debates in jurisprudence.

\footnotetext{
${ }^{52}$ See n 49.
} 


\subsection{Human agency}

Traditionally, the value of law has been understood to relate to its indispensability as a means of facilitating large scale social cooperation that aims at the attainment of important public goods, like safety, or the fulfilment of long-term political plans, like the industrialisation of an agricultural society. Plato's genealogy of law shows that he appreciates the relevant instrumental value of law. However, he also understands law to be valuable as a presupposition for the optimal operation of the human planning ability itself. As T6 makes clear, unless we are constrained by law we are bound to become akratic and thus unable to pursue any long-term plans without being constantly side-tracked by desires for short-term benefits. The danger of akrasia is particularly acute for rulers. Not only do rulers who shun the authority of law deprive themselves of an institution indispensable for the coordination of the actions of their subjects in line with their long-term political plans, but their own ability to consistently pursue those plans is significantly impaired. Their desires for short-term benefits are bound to get in the way and, other things being equal, the probability of their plans being frustrated due, not to external factors but, to their own inability to follow them rises.

What is the scope of Plato's thesis? In T6 he refers to cases of 'hard' akrasia, that is, cases in which one is aware at the time of action of the conflict between one's long-term benefit and one's desire for some short-term benefit. But we may plausibly expand his thesis to include various types of 'weak' akrasia, that is, cases in which desires for short-term benefits affect the absolute ruler's judgements about his long-term political benefit (by making him, for example, unable to see at the time of action the conflict between his longterm and short-term benefit). ${ }^{53}$

\footnotetext{
${ }^{53}$ For an application of Plato's analysis of akrasia as presented in the puppet image to cases of weak akrasia see Bobonich (n 34) 267-73.
} 
Is Plato's thesis plausible? Let us reflect on its status. On the one hand, it is a thesis about political psychology and as such its truth needs to be properly empirically tested. Recent research on the psychology of tyrants provides considerable evidential support: tyrants tend to suffer from malignant narcissism syndrome and power reinforces their narcissistic sense of invulnerability. ${ }^{54}$ On their political ascent the external constraints of the political environment they operate in help restrain their narcissistic desires. But once in power they develop a propensity to act out their most extreme fantasies that are based on fugacious desires or fears and exhibit manifest impulsivity. ${ }^{55}$

On the other, Plato's thesis purports to capture a political truth. This means that it would remain valid even if the study of political history were to identify comparatively few instances of absolute rulers who did not act on transient fantasies and impulses. In that case law would retain its value as a presupposition for the optimal operation of the long-term planning ability of most people.

\subsection{Tyranny}

Defenders of the thesis that the rule of law has inherent moral merit claim that it is incompatible with tyrannical regimes. According to Finnis, ‘[a] tyranny devoted to pernicious

\footnotetext{
${ }^{54}$ Betty Glad, 'Why Tyrants Go too Far: Malignant Narcissism and Absolute Power' (2002) 23 Political Psychology 1; cf. Jerrold M. Post, 'Current Concepts of the Narcissistic Personality: Implications for Political Psychology’ (1993) 14 Political Psychology 99.

${ }^{55}$ 'In the climb toward power, the would-be tyrant still has to work within the framework of certain external constraints. He has to pay homage to conventional values and attend to the interests and needs of others in power who can facilitate or impede his moves toward absolute power. He acts, in short, within a somewhat restrictive external framework. The environment, as it were, provides a kind of boundary for the self. His behavior thus is relatively reality oriented, and external constraints limit his acting out of fantasies, capping as it were the swirling mass of impulses underneath the surface. Once he has consolidated his position, however, a tyrant is apt to act out, with apparent impunity, the grandiose fantasies other people usually constrain. Secure in his political base and intoxicated by his early successes, the tyrant is apt to come to a point where he no longer thinks he needs to be careful and becomes convinced that he can act out his most extreme fantasies'. (Glad (n 54) 27-28)
} 
ends has no self-sufficient reason to submit itself to the discipline of operating consistently through the demanding processes of law, granted that the rational point of such self-discipline is the very value of reciprocity, fairness, and respect for person which the tyrant, ex hypothesi, holds in contempt'. ${ }^{56}$ Finnis refers, inter alia, to regimes that are 'exploitative, in that the rulers are out simply for their own interests regardless of the interests of the rest of the community'. No such exploitative tyranny 'can find in its objective any rationale for adherence (other than tactical and superficial) to the disciplines of legality. For such regimes are in the business for determinate results, not to help persons constitute themselves in community. 57

Kramer has recently challenged Finnis’s contention that exploitative tyrants would have no rationale for adhering to the rule of law. He argues that they would have strong prudential reasons to do so. Given law's role in securing large-scale co-ordination of social activities, other things being equal, the tyrants' adherence to the rule of law raises the probability that their exploitative plans will be implemented. ${ }^{58}$

Plato's account of the value of the rule of law suggests an alternative positivist riposte. Plato accepts that exploitative tyrannies are, as a matter of political reality, incompatible with the rule of law. But he would disagree with Finnis about, first, the explanation for their incompatibility, second, the reasons that rulers have to adhere to the rule of law and, third, the attitude that that rulers should exhibit if the rule of law is to obtain.

First, exploitative tyrannies are as a matter of political reality incompatible with the rule of law not because their ends are wicked but because tyrants are typically akratic agents, that is, they are unable to control their desires for even the slightest short-term political or

\footnotetext{
${ }^{56}$ Finnis (n 1) 273. Finnis’s italics.

57 Ibid 274.

${ }^{58}$ Matthew H. Kramer, In Defense of Legal Positivism (Oxford University Press 1999), 37-77.
} 
private benefit. Subsequently, they are unwilling to adhere to the norms of conduct that they legislate (other than in a 'tactical' or 'superficial' manner). Furthermore, given that in tyrannies the subjects lack any meaningful political power, there is no viable political mechanism to ensure that the tyrants' deviations from the norms that they have promulgated may be controlled.

Second, for Plato, the 'rational point' of the self-discipline that any ruler should exhibit in conforming to the rule of law is not promotion of the common good or any related moral values. Rather it is the attainment of enkrateia, that is, the ability of the ruler to pursue his long-term political plans without being side-tracked by his conflicting desires for shortterm political benefits. So, even tyrants have strong reasons to adhere to the rule of law. In addition to the kind of prudential reasons that Kramer identifies, other things being equal, their adherence to the rule of law raises the probability that their long-term planning ability operates optimally.

Third, to adhere to the rule of law the rulers of any regime need not be motivated by any genuine concern for the moral perfection of their subjects or even their material wellbeing. Since the rule of law can only obtain in regimes in which there is some political empowerment of the subjects, it suffices that the rulers show some political pragmatism in the circumstances and accept to share some power with their subjects. What ultimately motivates their pragmatic attitude may be simply their desire to hold onto power.

To conclude, a major lesson to draw from Plato’s legal positivism is to separate conditions of virtue from conditions of enkrateia. Even though in combination with education and culture law may help develop a morally virtuous political order, its point is to safeguard civic enkrateia and not virtue. 
